\title{
EXIT RIGHTS UNDER FEDERALISM
}

\author{
RichaRd A. EPSTEIN* \\ I \\ INTRODUCTION AND OVERVIEW
}

\section{A. The Government Monopolist}

Defenders of federalism, among whom I count myself, have long been attracted by the analogy to the market. When any individual is on the opposite side of the market from a large number of independent parties, then he is not dependent on any single party for any set of goods and services. The diffuse distribution of power allows everyone to search the market in order to obtain the lowest price for goods and services of any given quality. In competitive equilibrium, the price of these goods and services will equal their marginal cost, and everyone will emerge the happier. All goods that should be produced in the open market will be produced, and no goods that should not be produced will be produced. There will be neither unwarranted subsidy on the one hand, nor foregone opportunities on the other. Who could ask for more?

The rise of modern transaction cost economics has forced us, as defenders of markets, to moderate our optimism about the capacity of markets to clear in such an advantageous fashion. Today no one thinks that these market forces invariably will first find the perfect equilibrium and then maintain it over time. Rather, the argument is one of constrained optimism. There are persistent and powerful incentives that will draw market participants in the correct direction. It hardly matters that perfection is unobtainable, so long as the deviations from the ideal are as small as human institutions can make them. The best is not allowed to become the enemy of the good, and we embrace markets for the promise that they hold, and do not condemn them for the occasional disappointment that they yield.

The antithesis of a well-functioning market is of course the monopoly power of the government. When it comes to certain forms of critical goods and services, including those most closely related to self-preservation and defense, we have to turn to government. The story for that dependence is an old and well-told one, which lies at the root of the English social contract

\footnotetext{
Copyright $\odot 1992$ by Law and Contemporary Problems

* James Parker Hall Distinguished Service Professor of Law, The University of Chicago.

This paper was originally presented at the conference on Canadian and American constitutional law held at Duke University, April 4-6, 1991.
} 
theories,' ${ }^{1}$ and need not be rehearsed here. The alternative to a state with monopoly power over the use of force is a constant conflict of wills and clash of arms in which every person has the power to be a judge in his own cause. The abuses of a monopoly power are thought to be a small price to pay for the elimination of the greater difficulties of anarchy and the uncontrolled use of force.

But with all that said, the price that is involved is quite high; for monopolists, especially those who can eliminate or suppress rivals by force, are known to behave in a way that generates huge gains for those who control the tools of power at the cost of still greater losses to those who are subject to that power. The social inefficiency results in the excess of losses over gains. Yet, even if the naked force of government officials is effectively constrained, these parties still possess a fair measure of monopoly power. These officials will therefore have every incentive to behave like monopolists in other markets-by providing too little service at too high a price, the very vice that antitrust laws attack. The exact source of misbehavior in government is difficult to predict because power within government is divided among many persons and is partially checked by constitutional restraint. Small changes in the initial positions of public officials and private actors, and subtle differences in the individual strategies of these players, could lead to marked differences in outcomes. But these uncertainties in the process do nothing to negate the corrosive effect that government abuse can have on the operation of a well-functioning society, even if these uncertainties make it difficult to identify in advance how that abuse will manifest itself. All too often aggressive individuals and groups engage in relentless efforts to gain subsidies for themselves, or to impose taxes or regulations upon rivals, and this bewildering array of economic regulation of all sorts and descriptions cannot be explained by any optimistic public interest model of regulation. ${ }^{2}$ The forces of self-interest are all too often able, by a combination of influence and power, to commandeer and control the instruments of government. It is to guard against these risks that constitutions are established.

1. Thomas Hobbes, Leviathan (J.M. Dent \& Sons, 1973)(first published 1651); John Locke, A Second Treatise of Civil Government: An Essay Concerning the True Original, Extent, and End of Civil Government, in Thomas I. Cook, ed, Two Treatises of Government 121 (Hafner, 1947). Papers.

2. The suspicion of state power and democratic excesses was a familiar theme in the Federalist

The sober people of America are weary of the fluctuating policy which has directed the public councils. They have seen with regret and indignation that sudden changes and legislative interferences in cases affecting personal rights, become jobs in the hands of enterprising and influential speculators, and snares to the more-industrious and lessinformed part of the community. They have seen, too, that one legislative interference is but the first link of a long chain of repetitions, every subsequent interference being naturally produced by the effects of the preceding. They very rightly infer, therefore, that some thorough reform is wanting, which will banish speculations on public measures, inspire a general prudence and industry, and give a regular course of the business of society.

Federalist 44 (Madison), in Roy P. Fairfield, ed, The Federalist Papers 126, 128-29 (speaking of the Article I, $\$ 10$ limitations on the power of states, including a prohibition of the impairment of obligations of contract). 
There are three well-known strategies to counter these possibilities of government abuse. The first of these is separation of powers, and involves an effort to break up government power into constituent parts so that no individual or group gains access to all the monopoly levers. The second involves the protection of individual rights and liberties through a constitution and bill of rights that contains, most notably for these purposes, some form of property protection, although in other contexts protections of speech, press, and religion, and procedural due process may prove every bit as important. And the third is federalism, a system in which there are separate states or provinces that can be set into competition with one another. The individuals who are subject to state regulation need not be content with a "voice" in the political process but can protect their interests through the right of "exit," that is, through the ability to avoid the difficulties of further association by picking up stock and going elsewhere. ${ }^{3}$ The central focus of this paper is the role of federalism, with its attendant exit right for private individuals and firms, in checking the monopoly power of state or provincial government.

\section{B. Federalism as a Check on State Power}

There is some evident irony in viewing federalism as a check on the power of state governments. The system was not created by conscious design in the original constitution. Instead, it was an historical outgrowth of the previous institutional arrangement in which the separate colonies each had power over their internal affairs subject only to the external review by the English Parliament and Crown. At the original founding, the states were the dominant players and the federal government was their creature, conceived as a government with delegated powers specifically enumerated in Article I of the Constitution. ${ }^{4}$ The major impulse for the original constitutional design was to protect the states and their citizens against federal domination, that is, domination by a government so far removed from the people that it was likely to be insensitive to their liberties and concerns. There was less concern with the limitation of the powers of the state against its own citizens, and that those substantive provisions directed toward that end were cast as explicit substantive limitations on the power of the state. ${ }^{5}$ Instead, the major fear of

3. Albert Hirschman, Exit, Voice, and Loyalty: Responses to Decline in Firms, Organizations and States (Harvard U Press, 1970), the now obligatory citation. For its application to antitrust law, see Frank H. Easterbrook, Antitrust and the Economics of Federalism, $26 \mathrm{~J} \mathrm{~L} \&$ Econ 23, 28-50 (1983), and to land use decisions, see Carol Rose, Planning and Dealing: Piecemeal Land Contracts as a Problem of Local Legitimacy, 71 Cal L Rev 837, 901-12 (1983).

4. See US Const, Art I, $\$ 1$ ("All legislative Powers herein granted shall be vested in a Congress of the United States which shall consist of a Senate and a House of Representatives." (emphasis added)).

5. See id at $\S 10$. It is the provisions that are contained in this section that were the subject of Madison's attack on state power contained in Federalist 44, from which the brief passage was quoted in note 2. Unfortunately, Madison's discussion contains relatively little about the scope of the contracts clause, even though it does go into some length about the risks associated with allowing the states to coin their own money. 
state abuse was discrimination that any state might practice against the citizens of other states-a theme that is as important today as it was at the founding. ${ }^{6}$

The insight that federalism offered the prospects of structural limitations against the abuse of state power against its own citizens was not, as far as I can determine, part of the original constitution plan, but instead ranks only as a necessary and happy byproduct of that design. It is not possible therefore to find any early commentary that elaborates on the importance of federalism as a limitation on state power, so the arguments on the importance of federalism must be regarded as a modern reinterpretation of a fundamental constitutional structure in light of what we know to be the risks of government misconduct. Nonetheless, this element of competition between distinct states is an inseparable part of any federal system. It is important therefore to assess the role of federalism in preserving and organizing individual rights.

My conclusion is that while exit rights under federalism offer an important, indeed indispensable, safeguard against government abuse, the institution of federalism, without the rigorous enforcement of substantive individual rights, will not be equal to the formidable task before it. The great virtue of federalism is that it introduces an important measure of competition between governments. Federalism works best where it is possible to vote with your feet. The state that exploits its productive individuals runs the risk that they will take their business elsewhere. The exit threat therefore enforces the competitive regime. The weakness of federalism, standing alone, is that, in certain circumstances the presence of separate states within a federal union may not foster a competitive situation.

\section{Three Structural Weaknesses of Federalism}

There are three types of situations in which federalism provides insufficient protection for market institutions. First, certain assets are tied to particular locations for which jurisdictional competition and the exit threat are not sufficient to discipline state governments. Second, there are certain transactions in which an individual or firm cannot choose among states, but must enlist the cooperation of all states in order to carry on its business. Third, states may adopt counterstrategies, most notably exit taxes of various kinds, that can neutralize the exit threat that federalism normally affords to private individuals. These three risks are not trivial, for they cover a large percentage of the situations that arise within a federalist system.

In looking at these three structural problems, it is important to note that each has its precise analogue in the analysis of ordinary markets for goods and services. These private markets tend to work well until the monopoly element is injected. This monopoly problem can arise in either of two ways: first, when one party commits specific capital to a venture, as with investments that

6. See id at Art IV, $\S 2$ ("The Citizens of each State shall be entitled to all Privileges and Immunities of Citizens in the several States."). The diversity jurisdiction of Article III, $\S 2$ was also designed to counter local prejudice. 
are nonsalvageable at the conclusion of the venture by either abandonment, liquidation, or sale; or, second, when the coordination of multiple parties is necessary for any given project to be successful, as with a real estate developer that has to assemble many separate parcels of land in order to build. In both cases, the right to refuse to do business (the entrepreneur's analogue to the exit right) has certain major advantages in that it protects parties from outright confiscation of their assets by potential trading partners. The existence of the refusal to deal, therefore, will certainly influence the bargaining strategies of the private parties, and through it the level of goods and services that are produced and the prices at which they trade. In bankruptcy, for example, the ability of a trustee to gain an automatic stay against secured creditors who would otherwise liquidate their claims has enormous influence both on the shape of reorganization proceedings and the percentage of satisfaction of creditors' claims. ${ }^{7}$ Even the best bankruptcy rules will yield inferior outcomes in at least some cases, for it may well be that if the secured creditor with exit rights can remove and sell the secured property, the going concern value of the business will be lost unless the trustee and creditor can agree to a reconfiguration of rights after costly renegotiations. The same difficulty applies with individual exit rights within federalism, for there are cases in which their exercise could create dislocations as well. ${ }^{8}$ But these points are not decisive against federalism. Whatever its failings, federalism is an institution that improves the odds of forestalling government misconduct, even thought it cannot eliminate the entire risk of its occurrence.

In order to see both the strengths and limits of exit rights, the plan of action is as follows. The remainder of this paper is divided into four parts. Part II discusses two situations-the market for corporate control and the problem of environmental harm-in which exit rights are of value in constraining government power. The proposals to limit exit rights, or to encourage national solutions, to counteract "destructive" competition are generally misplaced. With that point first established, I turn next to some limitations on exit rights. Part III deals with the first of the limitations, the case in which exit rights are unable to protect specific investments within a given state. Part IV then deals with the coordination problem, where the ability to engage in business depends on the ability to do business in all states simultaneously. Finally, Part V considers state-imposed limitations on exit rights, a back-handed compliment for the indispensable place that exit rights have in any system of law.

7. For bankruptcy, see Douglas G. Baird \& Randal C. Picker, A Simple Noncooperative Bargaining Model of Corporate Reorganizations, $20 \mathrm{~J}$ Legal Studies 311, 312-13, 321-24 (1991).

8. See Lucian Ayre Bebchuk, Federalism and the Corporation: The Desirable Limits on State Competition in Corporate Law, 105 Harv L. Rev (forthcoming 1992)(sections III and IV of the draft on file with author). 


\section{Some Uses of Exit Rights}

\section{A. State Incorporation Law}

The question of competition between states arises in those areas in which states retain the primary power of regulation. One such area is the state power of incorporation, which is a source of extensive competition between the states. At present, major firms that do business in many states may pick a single state of incorporation. Incorporation is generally regarded as a good for the state of incorporation for the tax revenues it generates and the general business it provides. The battle between different states often centers on the inducements each could offer to promoters of new businesses to incorporate within their jurisdiction. Firms that do not like incorporation in one state can leave and reincorporate somewhere else. In some circles; this competition between states has been deplored as a "race to the bottom," on the ground that the managers will seek out that jurisdiction that is most favorable to their interests and, by implication, most adverse to the interests of prospective shareholders. ${ }^{9}$ On balance, however, incorporation is an area in which the exit right operates as a powerful instrument for the public welfare.

The "race to the bottom" claim is flawed because it misses the central point that the protection individual investors receive under a system of federalism is derived from their ability to withhold their consent. If the state incorporation laws allow the officers and directors of a corporation effectively to expropriate the wealth of shareholders, then, in the first instance, the original promoters of the new venture will have to bear the costs of those inferior rules. The rules are a matter of public knowledge, and if they are skewed in the way in which proponents of the race to the bottom believe, then initial investors (including institutional investors with great sophistication) will demand at incorporation more favorable terms to compensate themselves for the additional legal risks they are asked to assume. As that additional compensation will cost the promoters of the new venture more than compliance to a superior set of rules, the promoters will modify by contract any rules that facilitate the exploitation of shareholders. I am skeptical that there should be any mandatory terms within corporate charters, but if such are required, then competition between states within a federal system should spur states to identify those restrictions that are required and to reject those that are superfluous. ${ }^{10}$ The empirical evidence seems to be in accord with this

9. See, for example, id. For earlier contributions to the literature, see Ralph Nader, Mark Green \& Joel Seligman, Taming the Giant Corporation (W.W. Norton \& Co., 1976); William L. Cary, Federalism and Corporate Law: Reflections upon Delaware, 83 Yale L J 663 (1974) (arguing for federal chartering of corporations). The opposition to their position is developed in Ralph $\mathrm{K}$. Winter, Jr., Government and the Corporation (Am Enterprise Inst for Pub Policy Research, 1978); Daniel R. Fischel, The "Race to the Bottom" Revisited: Reflections on Recent Developments in Delaware Corporation Law, $76 \mathrm{Nw} \mathrm{U}$ L Rev 913 (1982).

10. For an extensive debate over these provisions, see Symposium, Lucian Ayre Bebchuk, et al, Contractual Freedom in Corporate Law, 89 Colum L Rev 1395 (1989). 
optimistic view, for those businesses that announce an intention to shift their state of incorporation to Delaware see significant advances in the value of their shares." In this situation, therefore, the exit right offers incentives for states to find the right mix between contractual freedom and state regulation.

Professor Bebchuk in his recent contribution on this issue notes that a shift in the place of doing corporate business could lead to risks to minority shareholders or to various creditors, both by tort and by contract. ${ }^{12}$ As regards dissident shareholders, the risk is surely there when majority vote and not unanimous consent is all that is necessary for reincorporation to take place. An additional requirement that no identifiable class of shareholders be left worse off after the reincorporation-a just compensation requirement for minority shareholders-could go a long way to prevent the abuses that might otherwise be allowable under majority voting. As regarding creditors, it is likely to be only the rare situation in which the reincorporation will benefit shareholders as a group, but at the same time will subject outside creditors (who otherwise benefit from the increased asset cushion) to greater risks than they sustained previously. If most shareholders are risk averse, it is unlikely they will support, even by a simple majority vote, any reincorporation in another state that increases the volatility of their holdings, the scenario most likely to prejudice any creditors. Since any federal law is so unlikely to represent a sensible response to any question of corporate governance, it seems best to rely on competition across states, notwithstanding the occasional case in which it might work more harm than good.

\section{B. Environmental Regulations}

The situation with respect to environmental regulation is more complicated, as there are elements of external harms that cannot be counted by ordinary markets, even in the absence of federalism. Thus, if state A induces a firm to locate within its borders by allowing it to pollute the air and water of state B, then the legal system has surely malfunctioned. But it is a mistake to insist that federalism solve a set of problems for which competition itself is not the answer. In the environmental context, the federalism option is no better than a rule that allows two private parties by agreement to inflict pollution losses upon a third party. A system of competition presupposes that goods and services are sold to third parties. It does not suppose that these third parties will be beaten or deceived. The problem of environmental spillovers across states is therefore one that the exit right cannot address, but for which alternative solutions are required. One possible solution under these circumstances is to allow the state in which the pollution has been discharged to maintain suit on behalf of its own citizens, either against the polluting firms or the states that have authorized the pollution in question.

11. Peter Dodd \& Richard Leftwich, The Market for Corporate Charters: "Unhealthy Competition" versus Federal Regulation, $53 \mathrm{~J}$ Bus 259 (1980). Note that those commentators who believe in the race to the bottom generally favor federal regulation.

12. Bebchuk, 105 Harv L Rev (cited in note 8)(section IV B2 of the draft on file with author). 
Still another solution is federal regulation of interstate pollution, as is now done under the Clean Water Act. ${ }^{3}$ The relative desirability of these two systems of social control is far beyond the scope of this paper. For these purposes, where the regulation of private conduct is justified under traditional tort principles, then the exit option-if relevant at all-should not be allowed to permit a firm to escape the consequences of its actions.

Even here, a word of caution is necessary, for the exit right assumes a far more attractive profile when one state seeks to attract new businesses, or to retain old ones, by excusing them from paying for purely local environmental damage. Under these circumstances, individual victims of environmental pollution may well be entitled to redress for the harm they have suffered, perhaps even as a matter of individual constitutional right, but rival firms in other states should not be entitled to intervene if the state does not exceed its constitutional powers relative to its own citizens. If local citizens are prepared, for example, to tolerate higher levels of pollution in exchange for their ability to manufacture goods at lower prices, then disappointed out-ofstate competitors should not be allowed to undo that decision in order to improve their relative competitive position. The danger of too much environmental regulation (as with excessive cleanups) ${ }^{14}$ is often as severe as the risk of too little regulation. The increased competition is of course galling to the aggrieved competitor, but federal regulation dealing with purely local pollution (for example, strip mining) is no more justified than is federal regulation preventing one state from adopting right-to-work laws on the ground that this form of state labor regulation provides local firms with a competitive advantage in the open market. Where all environmental losses are concentrated within the state, the exit option again has important virtues, for it permits firms to migrate away from states that have embarked on excessive programs of regulation. Subject therefore to the vital constraint of harms external to the state, the exit option does impose some valuable constraint on what local and state governments can do.

III

\section{Specific Assets Within Individual States}

In principle, then, there is no reason why one should be suspicious of the exit right in its own terms. While the right might not be sufficient to protect against all the various forms of state misconduct, it is surely an aid toward that direction. As the previous section pointed out some of the familiar strengths of the exit remedy, the next three sections point out some of its limitations.

13. Clean Water Act, Pub L No $92-500$ (1972), codified at 33 USC $\$ 1251$ et seq (1990),

14. Keith Schneider, U.S. Backing Away from Saying Dioxin is a Deadly Peril, NY Times Al col 6 (Aug 15, 1991). 


\section{A. Exit Rights of Developers and Landowners}

The first weakness of the exit right under the federalist system concerns cases with specific assets tied to a single jurisdiction. Consider the situation in which a plot of land is subject to comprehensive regulation by a zoning authority which has the power to decide whether certain land development projects should be allowed to go forward. The question arises what social losses, if any, can be caused by the zoning authority (which for these purposes we can assume will operate at a state-wide level) if it exercises its general power in an unwise fashion. In dealing with this question, it is often customary to examine the situation from the point of view of a developer and to conclude that the power of the zoning board is sharply limited because of local competition. ${ }^{15}$ If there were many different towns in which the development could take place, then the developer, who was faced with a set of powerful restrictions in the one town, could pack his bags and sell the project to some other location that desires the services in question. Where the power of regulation is vested in local governments, the distances that have to be moved are quite small so that the range of alternatives available to any single developer could be quite extensive. When the relevant unit of government is a state, the costs of exit are higher, but the exit threat can still be quite powerful. For example, it is generally recognized that state taxes are less progressive than national taxes because of the exit option, and several states have repealed their estate tax in order to stem the flow of retirees out of the jurisdiction. ${ }^{16}$

Yet it is also necessary to stress the limitations of the exit threat. To return to the real estate example again, it may well be that the developer has options to take the project elsewhere (a point to which I will come back to), but it surely does not follow that the landowner who wishes to sell to the developer has the same level of mobility or the same level of choices. ${ }^{17}$ Thus a decision by the local board to limit development to fancy houses on ten acre plots may cause only limited consternation to a developer, but the regulation can reduce

15. See, for example, Charles M. Tiebout, A Pure Theory of Local Expenditures, $64 \mathrm{~J}$ Pol Econ 416 (1956). Tiebout's argument was that so long as local governments had to compete for taxpayers, each would seek to find a niche that will allow consumers to locate the right mix of services and taxes. Some local governments could specialize in quality education, and others in facilities for retirees, so that individuals could gravitate to where they were most welcome. Thus, governments could be made to act at least a little like a market.

16. Prohibition of Gift and Death Taxes, 1982 Cal Stat ch 1535, $\S 13,301$, codified at Cal Rev and Tax Code $\S 13,301$ (West $1970 \&$ Supp 1991).

17. The fundamental difference in the position of the two parties is not taken into account in Vicki Been, "Exil" As a Constraint on Land Use Exactions: Rethinking the Unconstitutional Conditions Doctrine, 91 Colum L Rev 473, 500-04 (1991), discussing Nollan v California Coastal Commission, 483 US 825 (1987), criticizing my views on the case and commenting on Richard A. Epstein, Foreword: Unconstitutional Conditions, State Power, and the Limits of Consent, 102 Harv L Rev 4 (1988). Professor Been notes that the exit right will protect developers in land use contexts. Been, 91 Colum L Rev at 511 (cited in this note). However, Nollan involved a homeowner without an exit right, and, in any event, Professor Been overstates the value of the exit remedy. 
market value of the land by perhaps eighty or ninety percent. ${ }^{18}$ But the landowner is tied to the location, and so long as the political forces are aligned against him-nothing can stop the losses. Nothing, that is, unless there is some explicit takings protection against zoning-protections which, while available in principle, are not extensive against most forms of regulatory takings. ${ }^{19}$ These losses suffered by landowners are social losses, and by any measure the situation is an unfortunate one if the losses are greater than the gains that are obtained by the neighboring landowners who have imposed the regulation in the first place, which will typically be the case with large lot zoning and similar restrictions. The point here is not that all zoning restrictions should be regarded as improper as a matter of course; it is easy to think of certain restrictions on the location of signs, or for the payment of sewers and off-site improvements, for example, that are fully justified even under a system with a strong protection against takings. ${ }^{20}$ The negotiations between regulators and developers over these issues is often vexed, and some of the risk of expropriation, while reduced, still remains, for once matters have gone this far, the exit right is a threat that will prove of value only in rare situations.

It is important to stress, however, that the losses to the local landowners are not the only losses that will in fact take place. The developer in this instance has the right of exit and therefore is not trapped. But it should not be assumed that an exit right is every bit as good as an entrance right into a certain community. Quite the opposite. Exit serves only to mitigate the damages that are sustained by regulation. Yet to say that damages are mitigated is not to say that they have not occurred at all; nor is it to say that the damages that remain after mitigation are small. It may well be that the best counterstrategy available to a victim still leaves him bearing a very large loss. Presumably, the developer in question had some reason to prefer a site located in town A instead of town B. There may have been experience in dealing with local boards, or the developer may have established good connections with local contractors or suppliers, or have assembled marketing studies that allowed him to tailor a project to this locale. All of these local advantages are quickly lost if the landowner is blocked in his effort to make the deal with the outsider. The developer's opportunity cost of having to make do with the second best alternative, or perhaps third best alternative, is not trivial, given that the total cost involved in the project is usually a multiple of the value of the unimproved land. The usual model of competition

18. See, for example, the regulations sustained in HFH, Ltd. $v$ Superior Court of Los Angeles County, $15 \mathrm{Cal3d} 508$, 125 Cal Rptr 365, 542 P2d 237 (1975), where the value of the land with a commercial designation was $\$ 400,000$, but with a single family residential designation, it was only $\$ 75,000$.

19. See Euclid v Ambler Realty Co., 272 US 365 (1926), a case that set the stage for extensive regulation of land use in the United States, which has not been altered since that time. Euclid allows for virtually any form of "reasonable" land use regulation so long as it leaves the owner with some profitable use of the land. Today, the Supreme Court asks the wrong question: how much is left after regulation, rather than how much was taken by regulation?

20. See Richard A. Epstein, Takings: Private Property and the Power of Eminent Domain 266-67 (Harvard U Press, 1985). 
assumes that there are many suppliers of fungible goods in the market. But let the uniqueness of land be taken into account, and even partial fungibility cannot be assured. The developer who has invested in soil tests or marketing studies has a site-specific investment in a particular prospect even if he has no ownership claim to that land at all. He should be required to bear the risks that the owner will not sell the property, but he can protect himself against some portion of that risk through option contracts with the landowner. Let the zoning ordinances change the minimum lot size, however, and the exit option does nothing at all to protect the developer's site-specific investments.

Nor do the losses stop there, as there are potential customers of the potential developer who also might prefer this location to any other that is made available to them. Again being able to leave is not the same as being able to stay. The right to back out of a contract when the other side breaches should not be deprecated, but it offers far less protection than a remedy for expectation damages when the other side is in breach. To say that the exit remedy is sufficient is to say that walking away from a winning contract provides the promisee with the ideal remedy. In the contract context, some damage remedy is required to prevent misconduct by the parties, even if the damages are difficult to value and calculate. ${ }^{21}$ The same principle holds in the case of local regulation. The parallel between just compensation for the economic loss occasioned by the restriction on use, and expectation damages for the breach of contract is too close to be ignored. Both are one-time lump sum damages that are designed to leave the party paid indifferent between the continuation and termination of his particular project. The elimination of the contract remedy will lead to excessive breach; the elimination of the just compensation remedy will lead to excessive condemnation and regulation.

Carrying over these remedial ideals to the regulatory context is not easy. The just compensation principle should protect the expectations of both parties to the extent the expectations are realizable by the parties' combined actions. Yet it is difficult to quantify the losses, especially any that are borne by the developer. The precise details of these calculations, however, are not of concern here. What is evident is that the exit right does nothing to protect the losses of either landowner or developer. And where local governments can make their political decisions without internalizing the costs thereby imposed on the regulated parties, they will enact regulations desirable from the point of view of their electorate, but not necessarily from the point of view of the larger society.

21. For two studies of contract damage remedies under conditions of uncertainty, see Richard Craswell, Performance, Reliance, and One-Sided Information, 18 J Legal Studies 365 (1989); Steven Shavell, Damage Measures for Breach of Contract, 11 Bell J Econ 466 (1982). Shavell's work accepts as axiomatic the utility of damage measurements, but his first footnote lists several prior works on the economic role of damage measures. 


\section{B. Public Utilities}

Thus far I have stressed the problem of specific rents ${ }^{22}$ in connection with zoning, which is normally a local and not a state function. But the argument can be easily extended to other forms of regulation that are normally done at the state level. Regulation of utility rates and insurance markets are two obvious examples of such regulation, and each of them poses the same difficulty. Suppose that a power company invests heavily in order to develop a power plant to supply electricity or heat to a community, and that its rates and activities are subject to regulation by a Public Utility Commission ("PUC"). Here the PUC is normally given continuous power to regulate the activities of the utility, so that there is no once and for all contract that exists at the time the regulator starts its activities. Indeed there is early authority to the effect that the state could not contract away its police power (including the power of rate regulation) even if it tried to do so. ${ }^{23}$ Once the utility has committed its resources to the region, however, then there is the same risk of opportunistic behavior ${ }^{24}$ by government that is available to private parties whose trading partners have made initial investments. Unless there is specific protection against exploitation, the trading partner will try to expropriate quasi-rents from the party whose investment is complete, and will pay a price that is just large enough to keep that party in place (that is, to cover variable costs with a little something left over) without providing compensation for the initial front-end investment. Again the parallel between the contract situation and the eminent domain situation seems clear, and while there is much disagreement over the proper formula that should be used to determine the minimum rate of return made available to a public utility, everyone agrees that some compensation is required. ${ }^{25}$ The necessary implication is clear. The governments are part of the federal system, but the exit remedy is manifestly insufficient. Some explicit takings protection is required as well. The problem here is one of sufficient universality that it cannot be treated as a peculiarly American issue; it is equally applicable to Canada or any other modern industrial democracy. Just as competitive conditions do not hold when two firms have made contract-specific investments on the strength of a special relationship, so too the exit remedy loses much of its punch when a firm has invested heavily in specific resources within a given region.

22. For a concise definition of "rents" in the economic context, see John Eatwell, Murray Milgate \& Peter Newman, eds, The New Palgrave: A Dictionary of Economics 141 (Stockton Press, 1987).

23. See Stone v Mississippi, 101 US 814 (1879); see also dicta in Boyd v Alabama, 94 US 645, 650 (1876).

24. See, for example, Timothy J. Muris, Opportunistic Behavior and the Law of Contracts, 65 Minn L Rev 521 (1981).

25. Duquesne Light Co v Barasch, 488 US 299, 310-12 (1989). The Court upheld Pennsylvania's retroactive disallowance of the recovery of $\$ 43$ million in "reasonable and prudent" costs for a cancelled nuclear power plant. The Court noted that even with this recovery disallowed, the utility company was allowed a fair and reasonable return on its overall investment, which is all that the formula in Federal Power Comm. v Hope Natural Gas, 320 US 591, 602 (1944), requires. 


\section{IV}

\section{Coordination Problems across Jurisdictions}

\section{A. The Land Assembly Problem}

The use of market analogies also offers insight into a second limitation of the exit remedy. Recall that in ordinary markets the best results are obtained only when an individual purchaser is in a position to choose a contract with any one of a number of separate suppliers. There are certain situations, however, when it is necessary to have the cooperation of all the people on the opposite side of a transaction for it to go forward. In private markets, one common illustration of the problem is the land assembly question. A business wants to develop a unique site that is currently owned by a number of different individuals, but can only do so if all the plots are acquired. The value of the real estate in its unassembled form, when held by ten independent landowners, may be worth $\$ 100$ per plot, or $\$ 1,000$ altogether. But if all the plots can be brought under unified ownership, then for this particular project, the land has a value of $\$ 5,000$. Faced with this situation, the developer will take extraordinary precautions to keep hidden the nature of the ultimate project in order to keep the landowners ignorant of the value of the project to the developer. ${ }^{26}$ But if one of the landowners should find out, he could exact a price of up to $\$ 4,100$ for his plot of land without making the project unprofitable for the developer. ${ }^{27}$ If two or more landowners find out, then there could be elaborate strategic jockeying, with each seeking to hold out for the largest sum for his own parcel, knowing that other landowners have the same intentions. The combined demands of the present owners could easily exceed the $\$ 4,000$ in assembly value that the project promises, and if no one is prepared to mitigate demands, a profitable deal could be lost to everyone's detriment.

In these circumstances, one possible use of the eminent domain power is to allow the developer to acquire all the plots by a forced purchase at a price equal to, or even in excess of, market value. Without the forced purchase, strategic behavior by individual landowners could doom the project. With the forced purchase at the right price, the deal can go forward, and all parties can share the gains. The Mill Act disputes in the nineteenth century showed how important these issues have been in the development of the law of eminent domain. ${ }^{28}$ These statutes resolved the problem by allowing a landowner, typically with local approval, to flood the land of his neighbors upon payment of compensation for the land lost, often with some bonus value added. These Mill Acts, if operable at acceptable administrative costs, can work when ordinary market solutions are apt to fail because unanimous consent is

26. For the general rule that there is no duty to disclose, see Guaranty Safe Deposit and Trust Co. $v$ Liebold, 207 Pa 399, 404-05, 56 A 951, 953 (1904).

27. See, for discussion, Lloyd Cohen, Holdouts and Free Riders, 20 J Legal Studies 351 (1991).

28. See generally Head $v$ Amoskeag Mfg Co., 113 US 9 (1885). I have discussed the Mill Act cases in some detail in Epstein, Takings at $170-76$ (cited in note 20). 
necessary for a deal to go through. The ultimate irony is that the existence of a large and diffuse number of persons on the other side of the market is a sign of health when a large number of distinct, two-party contracts can yield substantial social gains. But the multiplicity of persons on one side of the market is a sign, and source, of genuine bargaining obstacles when the concurrence of all parties is necessary for a beneficial deal to go forward.

The problems of coordination and holdout can arise with great frequency within the federalism context. The most important nineteenth century illustration of the issue concerns the building and pricing on the transcontinental railroads, both in Canada and the United States. In order to build the long lines, it is necessary to acquire rights of way in many jurisdictions. Additionally, once the projects are built, there is a risk of regulation along each sector by a state or provincial government that will be able to expropriate the wealth of the railroad developer, who, in this situation, stands in an analogous position to the party who wants to assemble land for a new project. If any single state can impose restrictions on the part of the business that is located within its jurisdiction, then each state can seek to squeeze out the profits that are associated with the overall venture. Where there is no coordination among competing states, their inconsistent demands could easily exceed the net present value of the project, a form of total confiscation. Knowing that this possibility may await them, some entrepreneurs will avoid making the kinds of investments that will expose them to this sort of risk, or, if they do go forward, they alter their pattern of investment to minimize exposure.

\section{B. Multistate Coordination Problems}

The same sort of issue can arise in other more modern contexts as well. Many large firms are able to service their clients only if they are entitled to do business in all states or provinces. The decision by any state to exclude them will make it impossible to handle national clients. The insurance industry, for example, is often called upon to write insurance for risks that could occur anywhere in the country-workers' compensation for a major insured is one example. If the insurer cannot do business in a single state, then it cannot follow and adequately service its national risks. A policy that allowed any individual state to regulate or tax in a fashion that garnered all the profits from this line of business opens up the coordination and holdout problems of the land assembly case with a vengeance. It is quite possible that the sum total of the demands will exceed the gains from running the business, so that the competition of federalism becomes the destroyer and not the protector of markets.

Against this evident form of peril, it should be clear that the exit remedy is of no assistance whatsoever. Leaving the jurisdiction will not allow a bank, a broker, or an insurance company to service all the risks of its clients. Needing the cooperation of every state or every province, the firm cannot do its job simply by leaving those states that accord it a frosty welcome. The firm has to 
be able to force its way into states. At this point, the same type of solutions that are thought of for the assembly problem have to be considered. The state may be thought of as a common carrier with a monopoly position, which is therefore obligated to take all comers on a nondiscriminatory basis if they can meet certain minimum standards of conduct. Translated into practical terms, it means that a corporation licensed to do business in one jurisdiction should be able to receive, as of right, a license to do business in another jurisdiction so long as it renders itself amenable to service within the jurisdiction and satisfies the capital requirements that are imposed upon local firms. ${ }^{29}$ The basic principle is no longer one that allows states to turn down parties at will. Instead, like the obligations of a common carrier, a powerful nondiscrimination principle governs the entire field. The state is under a duty to treat the outsider on the same terms and conditions as its local firms.

This principle of nondiscrimination is applicable not only to the entry problem, but also to the question of state or provincial taxation of multi-state firms. ${ }^{30}$ If everyone thought that the exit remedy were sufficient for the occasion, then there would be no need to develop an elaborate set of rules that limit the way in which states may tax these far flung enterprises. The articulation of the extensive doctrine that has grown up in the opposite direction shows that exit is not enough. Thus, think of the business that has costs of $\$ 100$ in each of ten jurisdictions and profits of $\$ 10,000$ that can be made only if business is carried on simultaneously in all these states. To hold that discriminatory taxes are permissible is to allow each state to impose taxes up to $\$ 9,000$, which could well doom a profitable enterprise. Again the theory of government failure tracks the theory of market failure. The individual firm has to be able to force itself into the jurisdiction on even terms with its local competitors so that its going concern profit is not dissipated by the conduct of rival states. Here, too, the exit remedy is not enough.

\section{$\mathrm{V}$}

\section{State-Imposed Limits on Exit Rights}

The burden of the previous two sections has been to show that exit rights are insufficient to protect property rights over a broad range of circumstances. Nonetheless, it does not follow that these exit rights are of no importance in governing the relationships between the citizen and the state. The critical point is that exit rights do have an important role to play in a world in which the direct protection of property rights is, as it always. will be, insufficient. The availability of exit limits the degree of exploitation that is possible by the

29. For early cases that applied this principle, see Western Union Telegraph Co. v Kansas, 216 US 1 (1910); Southern Railway v Greene, 216 US 400 (1910). There are exceptions to the nondiscrimination rule, see, for example, Western $\mathcal{E}$ Southern Life Insurance Co. $v$ Board of Equalization, 45I US 648, 652-55 (1981) (Congress waived commerce clause protection for insurance company). I have analyzed the doctrine in Epstein, 102 Harv L Rev at $31-40$ (cited in note 17).

30. See, for example, Complete Auto Transit, Inc. v Brady, 430 US 274 (1977); for an exhaustive analysis, see Walter Hellerstein, State Taxation of Interstate Business: Perspectives on Two Centuries of Constitutional Adjudication, 41 Tax Lawyer 37 (1987). 
state. But all too often when exploitation is attempted through regulation, the power of the exit remedy is revealed by indirection, in the willingness of the state to limit it by taxation or regulation.

The problem may be illustrated by the following example, drawn from the situation as it exists in the automobile insurance industry both in New Jersey and Massachusetts. ${ }^{31}$ In stylized form, the state has a system of rate regulation that promises a rate of return that the regulated industry regards as insufficient. The regulated firms challenge those state regulations in court and lose on some substantive or procedural ground. A company then decides to leave the jurisdiction and is willing to abandon specific capital located within the state and to lose the benefit of all business that requires it to be within the state. The state, however, does not wish to see the firm go, for if the insurer leaves two things will happen: a large portion of the state's market will not be serviced and the absent firm will be unable to make contributions that are necessary to prop up an assigned risk pool of drivers who cannot obtain insurance in the voluntary market. Given the existing level of regulation, it is highly unlikely that any new insurance firm will decide to do business within the state. So it is a question of how the insurer can be kept doing business within the state against its will.

\section{A. Effect of Exit Taxes}

It is here that the exit tax becomes critical. Suppose that without the exit tax the decision to leave the state will cost the firm $\$ 1,000$. The firm will then decide to stay in the state so long as the present value of the confiscation it will suffer in future years under regulation is in the aggregate kept below $\$ 999$. The exit right thus limits the amount of loss that will be suffered, even if it will not prevent the abuse from occurring. But now suppose that a $\$ 500$ exit tax is imposed, which is an amount that the state says it will need to fund the firm's share of the assigned risk pool over some future period. If the tax itself is valid, then it may never be collected directly, because the firm will decide to stay if the present value of its future losses under regulation are anticipated to be lower than $\$ 1,499$. If the firm leaves, with the tax being valid, the state will be the better by $\$ 500$, even though the state can hardly claim to be providing services or benefits to the firm that has decided to leave the jurisdiction. Either way, therefore, if the tax is effective, it operates as a partial nullification of the exit right and as an increase in the scope of confiscation that is possible under the regulatory scheme.

31. See New Jersey Fair Automobile Insurance Reform Act of 1990, NJ Stat Ann $\$$ 17:33 B-l et seq (West 1985 \& Supp 1991); Mass Ann Laws, ch 175, § 22H (Michie/Law Coop 1987). The Commonwealth Automobile Reinsurers ("CAR") Rule 11 B.3, propagated under the authority of $\$ 22 \mathrm{H}$ of chapter 175 , provides that any insurer that wishes to abandon its license to sell automobile insurance and retain its other state licenses must make payments into the assigned risk pool for eight years after it withdraws from that market. See Aetna Casualty and Surety Co. v Gailey, 753 F Supp 46 (D) Mass 1990), refusing to dismiss Aetna's challenge to Rule 11 B.3 on ripeness grounds. I have been involved in the litigation in New Jersey as a consultant to Allstate Insurance Company. 
In making this point, it should be noted that the exit tax 'could take many forms. In addition to a simple cash levy that is based upon some volume of past business, it is also possible to impose obligations in kind. For example, the firm's departure could be delayed until the firm was able to secure some other firm to cover its business for some period of future years. ${ }^{32}$ During the period of transition, the insurer might be required to write coverage at the old regulated rates or the firm could be expected to pay a successor corporation some sum of money in order to pick up that which is otherwise a losing book of business. ${ }^{33}$ But these details are not relevant to the central theme: if the exit tax is allowed to compromise the exit right, then the prospect of exploitation against which federalism guards is thereby increased.

The solution seems clear enough. There ought to be a categorical rule against these exit taxes, so that the firms that do choose to leave can do so without the fear of facing extensive litigation and penalties for exercising their choices. Ever since Ex parte Young, ${ }^{34}$ if not before, it has been widely recognized that it is intolerable to require a firm to break a law in order to test the law's constitutionality. In many circumstances a declaratory judgment action is the way to avoid the difficulty, but the case law with respect to takings is emphatic on the point that these anticipatory challenges to state regulations are not allowed. Administrative remedies, no matter how cumbersome and slow, must be exhausted before the administrative relief will be provided, for there are no facial challenges to comprehensive regulatory schemes. ${ }^{35}$ Here the form of relief does nothing to ease the sting. So long as the previous regime continues in place until the judgment is obtained, there is an increased loss from having to operate under the impermissible scheme. The exit right exerts its greatest effects on local governments where a firm is allowed to pick up stakes and leave at will, without having to demonstrate the unreasonableness of local regulations to the state that promulgated them or to a court that never has had to live under their yoke.

The case for having that categorical exit right is very strong once it is recalled that no firm has ever exploited its consumers by seeking to go out of business. By exiting, a firm is announcing that it regards the regulated rate of return as negative. More concretely, the firm views its losses under regulation as greater than its losses through leaving, which are equal to its losses on existing assets plus the loss of any future business opportunities within the

32. See, for example, Cal Ins Code $\$ 1861.03$ (c) (West $1972 \&$ Supp 1991) (requiring renewal except for nonpayment of premium or substantial increase in insurable risk).

33. See the California decision in Travelers Indemnity Co. v Gillespie, 50 Cal3d 82, 266 Cal Rptr 117, 785 P2d 500 (1990), which, in its interpretation of California Proposition 103, held that Travelers was entitled to exit the state so long as it found a successor corporation that was prepared to assume its liabilities for renewal for a single year. The decision did not pass on the question whether the perpetual obligation to renew could be imposed.

34. 209 US 123, 147-48 (1908).

35. See, for example, Hodel v Virginia Surface Mining î Reclamation Association, 452 US 264, 297 (1981); State Farm Insurance Co. $v$ State of New Jersey, 124 NJ 32, 590 A2d 191 (1991) (sustaining NJ Stat Ann $\$ 17: 33$ B-5I against a facial constitutional challenge). 
state. No firm will easily make the decision to exit if it is in fact making a decent return on its invested capital.

The game here thus differs fundamentally from that which is played where a firm under regulation challenges its rate structure but still is willing to provide the necessary service. In that case, it is quite possible that the firm is seeking nothing more than a disguised monopoly rent. So long as the firm is prepared to stay in the state, that possibility cannot be ruled out in principle. It is of course possible that the firm's claim of confiscation is valid, but at a limited level where it is more prudent to stay and fight than it is to leave. But the relevant judgment that the regulation is oppressive is far easier to make whenever the firm is prepared to vote with its feet, for now there is no scenario that allows it to make a profit under regulation. As that is the case, the categorical prohibition against exit taxes is an effective way to prevent the abuses that now abound in state regulatory processes.

\section{B. Exit Rights and Existing Liabilities}

There is still one further complication, however. Suppose that the firm has decided to exit the state because it is worried about the firm's liabilities under existing contracts, and wishes to leave to avoid paying those liabilities when they come due. That problem always exists, for example, under insurance contracts where the obligation of the insured to pay premiums is incurred by the insured before the insurance company comes under its obligation to pay out losses. Indeed the early systems of regulation were justified, and rightly justified, to make sure that companies did not engage in strategic behavior to avoid their contractual liabilities. To guard against this prospect, insurers are required to establish reserves for their anticipated losses, and should not be able to defeat the reserve requirements by exercising any constitutionally protected exit option.

But those reserve requirements only clarify that the state could require the firm to remain within the state in order to answer claims on existing contracts. Perhaps the firm might be required to place some money on deposit within the state so that in-state plaintiffs are not required to bring suit in a foreign jurisdiction to vindicate a contract right established within the state. The obligations here are hardly novel. They are not different from those that are imposed when any other company wants to liquidate before its contract obligations are discharged. But if the question is whether the firm must continue to write new contracts at a loss, then there is no risk of taking money today and not paying out tomorrow. The basic theme still remains compelling. The exit option should be preserved against that form of taxation. No firm that has achieved a just rate of return will choose to leave. Federalism and exit rights under it therefore form an essential backstop against state exploitation, one that becomes ever more important as the direct protections against confiscation through regulation become weaker. It is probably a sign of the times, at least on the American side, that the toleration of exit taxes becomes greater as the concern over confiscation diminishes. 
Indeed one way to understand this problem is to recognize that any state claim to impose an exit tax (or even a requirement to keep the firm doing business within the state) will rest as ever on the operation of the police power, which is here said to be sufficient to allow the state to take steps to maintain an orderly market when the withdrawal is threatened. ${ }^{36}$ This claim would have a certain sense if it were assumed that the breakdown in the market were attributable to sudden and unforeseen events that are beyond the power of the state to prevent-war and famine come most quickly to mind. But the breakdown in the market is a direct function of the system of regulation that chokes off profitability and innovation in competitive markets. To have the state first create the crisis with a set of stringent regulations and then use that crisis to justify still more extensive state regulation is an open invitation for government irresponsibility. The restrictions on profits, and the obligations to fund an assigned risk pool, induce existing firms to reduce their market share and operate as a storm signal that induces other firms to stay out of the market. The capacity shortage in the automobile insurance industry is related directly to the limitations on price.

\section{VI}

\section{ConClusion}

The great advantage of the exit remedy is its self-help nature, which may make it preferable to legal remedies (such as a regulatory decision to grant an appropriate rate increase) that in principle may offer more substantial relief, but which also cost more to achieve. To say that federalism remedies may be cut off by a state whenever there is no clear declaration of a substantive government wrong is to carry over the relaxed views on individual property rights to another arena and to compound a major problem. Exit rights are to federalism as the right to reject defective goods is to the law of sales. Neither remedy places the injured party in the place he would have enjoyed if a fully adequate set of remedies had been provided. The buyer armed only with the right of rejection cannot recover her lost profits on a contract of sale. ${ }^{37}$ The individual armed only with the right to leave the state cannot get a just rate of return on the investment in the state. Thus both self-help and legal remedies are worthy of enforcement in both the private and the public context. Our courts, both state and federal, should not allow the state or provincial governments to fritter away these important protections of individual property rights.

36. See, for example, Fair Automobile Insurance Reform Act of 1990, § 72, 1990 NJ Sess Law Serv 8 (West), codified at NJ Stat Ann $\$ 17: 33$ B-30.

37. See, for example, UCC $\$ 2-711$ (Am L Inst, 1990). 
